\title{
Effects of the defoliation height on the growth, mineral uptake and soluble carbohydrate contents in berseem clover (Trifolium alexandrinum L.) var. Khadhraoui
}

\author{
Mezni* ${ }^{1}$ M., Haffani ${ }^{1}$ S., Khamassi ${ }^{2}$ N., Albouchi ${ }^{3}$ A. \\ ${ }^{I}$ Université de Carthage. Laboratoire des Productions Animales et Fourragères. INRAT, Rue Hédi Karray \\ 2049, Ariana, Tunisie. \\ ${ }^{2}$ Laboratoire de Physiologie Végétale, Faculté des Sciences de Tunis. Campus Universitaire, 1060, le \\ Belvédère, Tunis, Tunisie. \\ ${ }^{3}$ Unité d'Agro-Sylvo-Pastoralisme. INRGREF, BP 10, 2080, Ariana, Tunisie.
}

\begin{abstract}
In a pot experiment the responses of berseem clover (Trifolium alexandrinum L.) var. Khadhraoui to the defoliation heights (2.5 -5 -7.5 and 10cm) were evaluated in terms of shoot and root growth, $\mathrm{K}^{+}, \mathrm{Ca}^{2+}$ and $\mathrm{P}$ inorganic uptake and soluble carbohydrates. Plants were grown in green house under natural light and temperature. The experimental was conducted using a complete randomized block design with 4 repetitions. Berseem was defoliated when plants achieved $50 \mathrm{~cm}$ of height. Results showed that the cumulative dry material varies with the defoliation height. In the sixth harvest treatment, DM under the $5 \mathrm{~cm}$ cutting height was significantly higher than in the other treatments. The leaf area (LA) per plant showed a depressive effect of the extreme defoliations: shorter $(2.5 \mathrm{~cm})$ and higher $(10 \mathrm{~cm})$, while the cutting heights at 5 and $7.5 \mathrm{~cm}$ present a LA appreciably similar. The specific leaf area (SLA) decreases with the increase in the defoliation heights and a significant difference is observed between plants defoliated at 2.5 and $5 \mathrm{~cm}$, on one hand and those harvested at 7.5 and $10 \mathrm{~cm}$, on the other hand. The Stem/Leave ratio is a good index for the appreciation of fodder quality. Indeed, the defoliation heights at 2.5 and $5 \mathrm{~cm}$ have a fodder quality better than those defoliated at 7.5 and $10 \mathrm{~cm}$. Compared to the other treatments, the Shoot/Root ratio under the defoliation height of $5 \mathrm{~cm}$ was the lowest. $K^{+}$content in roots, stems and leaves decreased with the increase in the defoliation heights. Calcium content was not affected by the defoliation heights. The phosphorus decreased significantly with the cutting heights and the time of the harvest in the three organs of the berseem Khadhraoui. The soluble sugar contents in roots, stems and leaves of the berseem showed a severe decline in the root system. Results suggest that soluble carbohydrate reserves in roots can support plants regrowth after defoliation.
\end{abstract}

Keywords: Berseem, Calcium, Defoliation height, Growth parameters, Phosphorus, Potassium, Soluble carbohydrates.

\section{Introduction}

In Tunisia, the development of the livestock, a priority sector of the agricultural production, largely relies on the availability of feed resources mainly cultivated forage. The most used fodder belongs to the two botanical families: Grasses and Legumes which are selected to support successive cuttings for dry matter production throughout their vegetative cycle (Tessama et al., 2010). The berseem is widely cultivated in Tunisia. Berseem clover is an annual forage legume, commonly subjected to repeated cycles of defoliation and regrowth (Iannucci and Martiniello, 2000). This specie is an important legume due to its high content of proteins (De Santis et al., 2004), and because of its capacity to improve soil fertility by the organic matter and the symbiotic fixation of the atmospheric nitrogen (Mezni et Sifi, 1995). The berseem clover tolerates the low temperatures of the winter and vegetates after each harvest. The berseem is sown either alone or in mixture with ryegrass (Lolium multiflorum $\mathbf{L}$.). The use of the mixture of berseem-ryegrass increased the total herbage yield, produced forage with high proteins and at lower cost (Mezni et al., 2000 ; Peyraud et al., 2009 ; Giambalvo et al., 2011a). Plant cutting or defoliation is a mechanical stress which deprives the plant of its system photosynthetic (leaves) and can compromise its growth and development. The regrowth will depend largely on the speed with which the defoliated plant can replace its foliar system. The cutting height is a very important parameter which influenced the plant yield, the quality of the harvested forage and the plant regeneration speed and the sustainability of the culture (Vinther, 2006 ; Baatar, 2008 ; El-Morsy, 2009 ; Wijitphan et al., 2009 ; Da Silveira et al., 2010 ; Chen et al., 2012; Onyeonagu and Ugwuanyi, 2012).

In berseem, after defoliation, two types of stems ensure the regrowth. Indeed, as reported by Dufour et al., (1989), (i) stems appeared on the basis remainder of stems left after cutting and (ii) stems directly regenerated from the crown. In a study on the effect of the intensity and the cutting height on Lucerne, Leach 
(1968) showed that the severe defoliation highlights the role of leaves left after the cutting (residual leaf area), in the regeneration of the plant shoots.

Undersander and Pinkerton, (1989) and Dhont et al., (2006) indicated that the cutting management of alfalfa determines both the quality of the harvested forage and the health and stand life of the crop. In Berseem clover, Giambalvo et al., (2011b) noted that defoliation management of the forage crops affects endogenous reserves in the crowns and the taproots, the residual leaf area, and, consequently, the regrowth and biomass yield. Indeed, the regrowth of forage legumes after each harvest depends on energy reserves stored in the taproots and the crowns of the plants (Berthier et al., 2009). In practice, farmers have to take into account three points: (i) maximize yield, (ii) maintaining high quality forages and (iii) plant longevity.

The regrowth after the defoliation depends initially on the development of the photosynthetic leaves. The photosynthesis decreases severely, after defoliation or grazing (Schnyder and De Visser, 1999; Avice et al., 2001). So, after the defoliation, the capacity of photosynthesis decreases and the regeneration will depend on the mobilization of the organic reserves (C and N) to the defoliated plants (Johansson, 1993; Goulas et al., 2002; Amiard et al., 2003; Meuriot et al., 2004 ; Lestienne et al., 2006; Lee et al., 2010). Several authors highlighted the importance of the carbohydrates and proteins reserves in the regrowth of plants after the defoliation (Gordon et al., 1999 ; Morvan-Bertrand et al., 1999 ; Simon et al., 2004). The objective of this work was to analyze the physiological and agronomical response of the berseem clover var. Khadhraoui to four cutting heights in terms of an optimal dry matter production with high protein contents.

\section{Plant material and growth conditions}

\section{Materials and methods}

The choice of the local berseem clover (Trifolium alexandrinum) var. khadhraoui in this study was its wide use in the irrigated area for the feeding of dairy cattle. Under irrigation, this variety can give annually 6 to 8 harvests. Four cutting height levels $(2.5-5-7.5$ and $10 \mathrm{~cm})$ up the crown were applied on the khadhraoui variety. The experiment was carried out under greenhouse in a randomized complete block design with four replicates $(1$ variety $\mathrm{x} 4$ treatments $\mathrm{x} 4$ replications $=16$ pots $)$. The sowing was carried using thirteen pregerminating seeds per pot. Cement pots contained $22 \mathrm{~kg}$ of basic soil $(\mathrm{pH}=8.2)$, rich in active chalk $(7.5 \%)$, with a humidity fluctuating between: $7.8 \%$ at wilting point and $17.5 \%$ at field capacity (table 1). Pots were irrigated daily with tap water and continuously drained.

Table 1. Chemical and physical soil properties at the experimental site.

\begin{tabular}{ll}
\hline Parameters & Values \\
\hline Humidity at field capacity (\%) & 17.5 \\
Humidity at wilting point (\%) & 7.8 \\
Clay (\%) & 25.0 \\
Loam (\%) & 39.5 \\
Sand (\%) & 44.0 \\
pH & 8.3 \\
Electric conductivity (mmhos/cm) & 3.5 \\
Total chalk (\%) & 14.5 \\
Active chalk (\%) & 7.5 \\
Organic matter (\%) & 0.73 \\
Carbon & 0.4 \\
Saturation $\mathrm{ml} / 100 \mathrm{~g}$ & 25.0 \\
\hline
\end{tabular}

\section{Measurement of parameters}

The growth parameters (leaf area, shoots and roots dry matter) were determined when plant height achieved $50 \mathrm{~cm}$. Before each harvest, one plant per pot was carefully pulled up and then separated into roots and shoots. Dry matter of different organs (leaves, stems and roots) was obtained by desiccation at $70^{\circ} \mathrm{C}$. The leaf area (LA) was calculated by the method of weighting, on leaves completely developed. Leaves are quickly photocopied and their imprints carefully are cut and weighed. The LA was then deducted, with the weight of a known surface. The LA per plant was obtained by multiplying the LA average by the corresponding leaves number (Garcia et al., 2002). The specific leaf area (SLA) designed the ratio of leaf area to leaf dry mass and expressed in $\mathrm{cm}^{2} . \mathrm{mg}^{-1}$ leaves DM (Garnier et al., 2001).

Mineral analysis $\left(\mathrm{K}^{+}, \mathrm{Ca}^{2+}\right.$ and $\left.\left(\mathrm{PO}_{4}\right)^{3-}\right)$ and carbohydrates were carried out on lyophilized samples, harvested when plants reached $50 \mathrm{~cm}$ of height. Extraction of cations was achieved using the nitric technique (nitric acid to $0.5 \%$ ). The $\mathrm{K}^{+}, \mathrm{Ca}^{++}$, were measured by a flame photometer (Eppendorf photometer). The phosphate ion was measured by photocolorimetry at a wavelength of $420 \mathrm{~nm}$. Carbohydrates were extracted with boiling alcohol at $70^{\circ}$. Total soluble sugar was determinate using a colorimetric method at $470 \mathrm{~nm}$ wavelengths. 


\section{Statistical analysis}

Confidence intervals were calculated to the threshold of 95\% probability. General Linear Models of SAS was used to explain the degree of significance of each factor and of the interactions between different factors. The Duncan test was used to compare treatment means for all studied parameters.

\section{Shoot dry matter $(D M)$}

\section{Results}

Figure 1 represents the variation of the shoot dry matter per defoliation according to the cutting heights. Results showed that dry matter varies with the increase of the defoliation height, according to a polynomial function of type: $y=a x^{2}+b x+c$, Where $\mathbf{y}$ represents the DM $(\mathrm{g})$ and $\underline{\mathbf{x}}$ the defoliation height $(\mathrm{cm})$. For the six harvests, the DM was the highest under the defoliation height of $5 \mathrm{~cm}$ (except the $\mathrm{C} 2$ ).

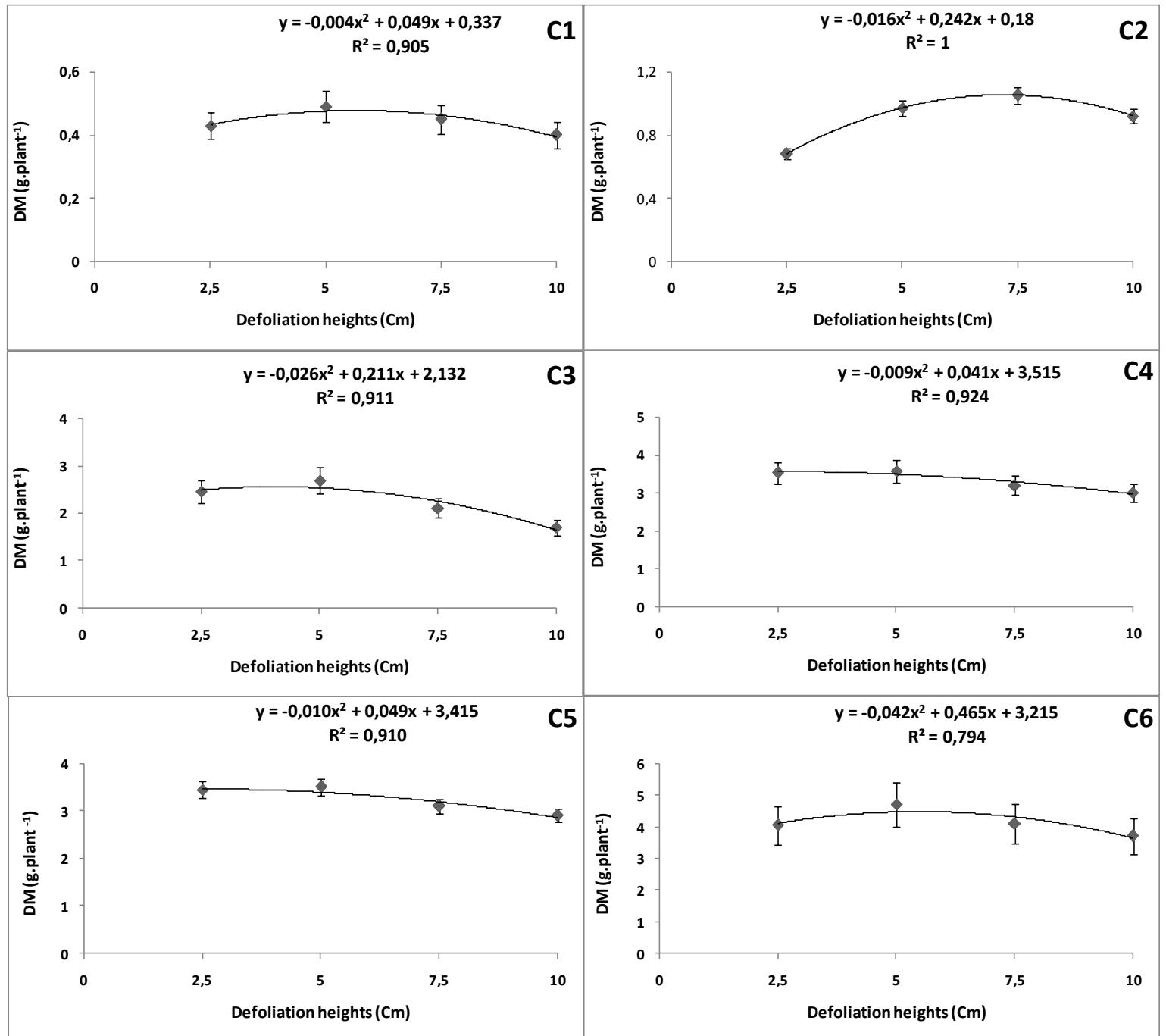

Figure 1. Shoot DM, under defoliation heights $(2.5-5-7.5$ and $10 \mathrm{~cm})$ on the berseem Khadhraoui. Each point is the mean of 4 individual values. Intervals of confidence were calculated at $\alpha=95 \%$.

Figure 2 showed that cumulated DM was significantly higher under the defoliation height of $5 \mathrm{~cm}$, compared to $10 \mathrm{~cm}$ treatment starting from the third harvest; while DM was significantly different with $7.5 \mathrm{~cm}$ treatment only from the fourth harvest (C4). There was no significant difference between defoliation heights of 2.5 and $7.5 \mathrm{~cm}$, and this is for all the harvests. 


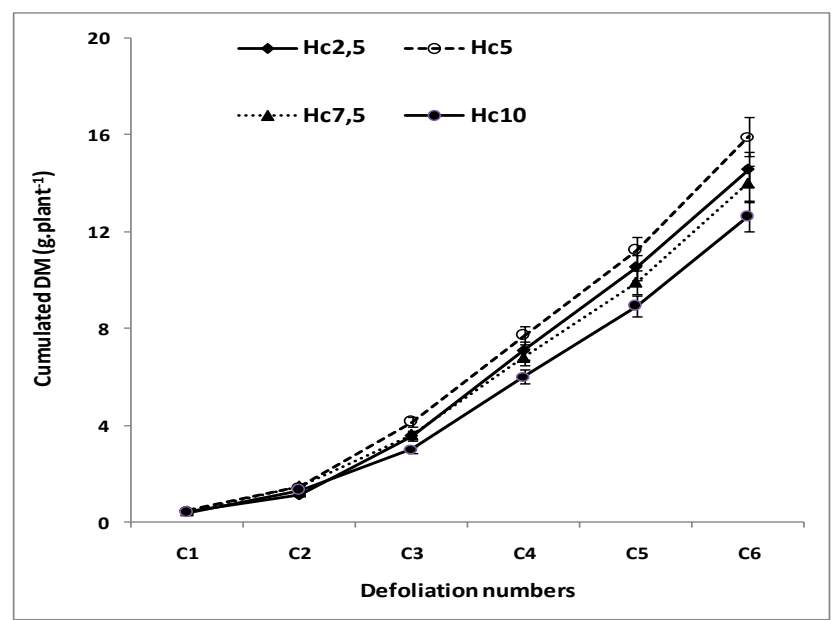

Figure 2. Variation of cumulated shoot DM, with the defoliation numbers on the berseem Khadhraoui. Each point is the mean of 4 individual values. Intervals of confidence were calculated at $\alpha=95 \%$.

\section{Leaf/stem $(L / S)$ ratio.}

The leaf/stem ratio is a very important agronomic criterion which expresses the fodder quality of the plant and shows the energy value of the specie (Lemaire et al., 1994). Figure 3 represents the variation of the $\mathrm{L} / \mathrm{S}$ ratio in relation to the defoliation heights. Results show that the L/S ratio decreases linearly with the increase in the defoliation heights. The decrease in L/S ratio can be explained by the senescence of the old leaves, left below the defoliation at 7.5 and $10 \mathrm{~cm}$ height. While the stem dry matter is constituted by the stems neoformed but also by a part of the rests of the previous cut which exceeded the defoliation height recommended.

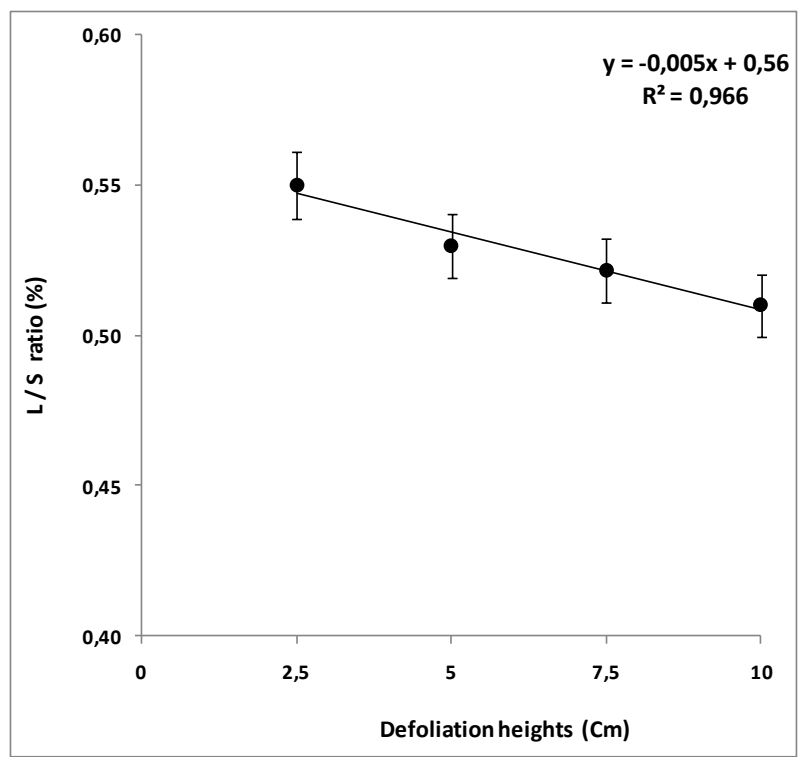

Figure 3. Leaf/stem (L/S) ratio under defoliation heights $(2.5-5-7.5$ and $10 \mathrm{~cm})$ on the berseem Khadhraoui. Each point represents the mean of 4 individual values. Intervals of confidence were calculated at $\alpha=95 \%$.

\section{Cumulated shoot and root dry matter and Shoot to Root (S/R) ratio.}

To explain Shoot/Root ratio (figure 4B), we look at the variation of the dry matter of shoots and roots (figure 4A). The dry matter, in shoot and root, is affected by the defoliation height in the same direction. The DM under the defoliation height of $5 \mathrm{~cm}$ was the highest. The $S / R$ ratio varies with the defoliation heights according to a hyperbolic curve: $\mathrm{y}=\mathrm{ax}^{2}+\mathrm{bx}+\mathrm{c}$; where $\mathbf{y}$ represents the $(\mathrm{S} / \mathrm{R})$ ratio and $\underline{\mathbf{x}}$ the defoliation height $(\mathrm{cm})$. It appeared that the $\mathrm{S} / \mathrm{R}$ ratio under the defoliation height of $5 \mathrm{~cm}$ is the lowest $(\mathrm{P}<0.05)$, compared to the other treatments. This indicates that the root DM increases under the defoliation height of $5 \mathrm{~cm}$ faster than that of the shoot DM. 

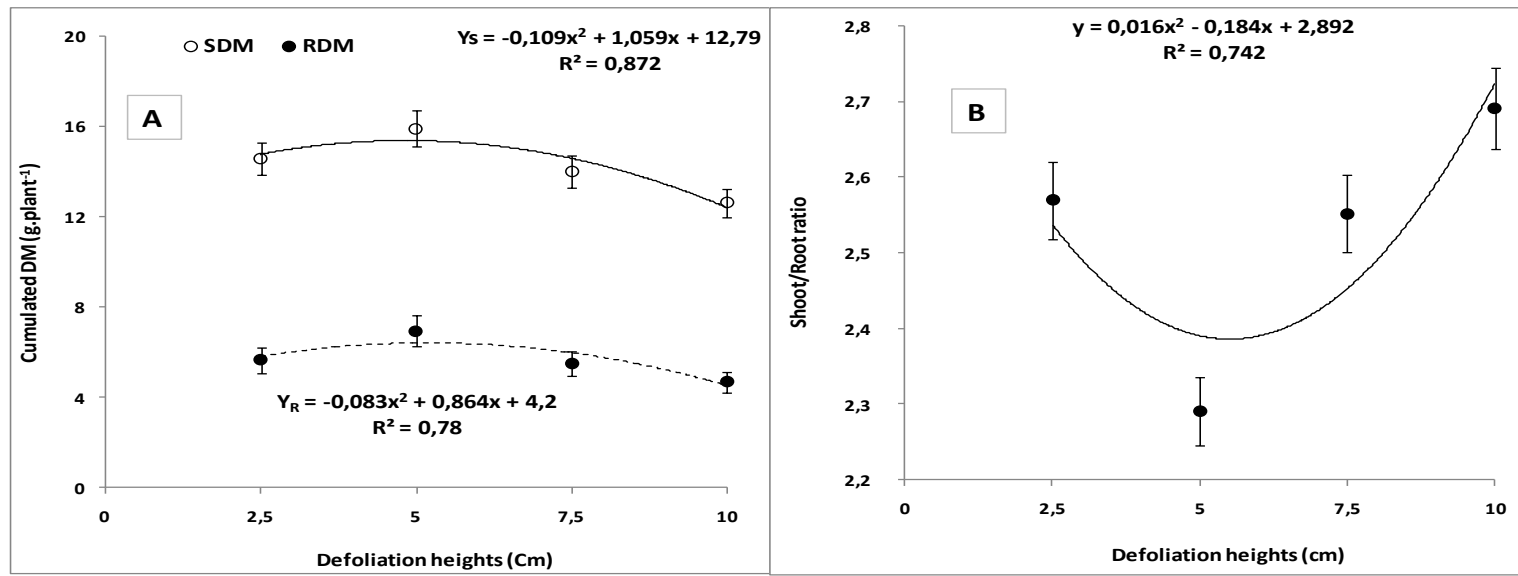

Figure 4. Shoot (SDM) and Root (RDM) cumulated DM $(\underline{\mathbf{A}})$ and Shoot/Root ratio $(\underline{\mathbf{B}})$ under defoliation heights $(2.5-5-7.5$ and $10 \mathrm{~cm})$ on the berseem Khadhraoui. Each point is the mean of 4 individual values. Intervals of confidence were calculated at $\alpha=95 \%$.

\section{Leaf area $($ LA)}

Leaves constitute the most active organ of the plant. They are the site of photosynthesis and transpiration. Plants growing under good conditions of water and mineral supply have as a priority the acquisition of an important leaf area, with the aim of an additional accumulation of biomass. To examine the impact of the defoliation height variation, we measured the leaf area in each harvest (figure 5). The results showed that the leaf area under the defoliation height of $5 \mathrm{~cm}$ was significantly higher, than that in the extreme treatments $(2.5$ and $10 \mathrm{~cm})$.

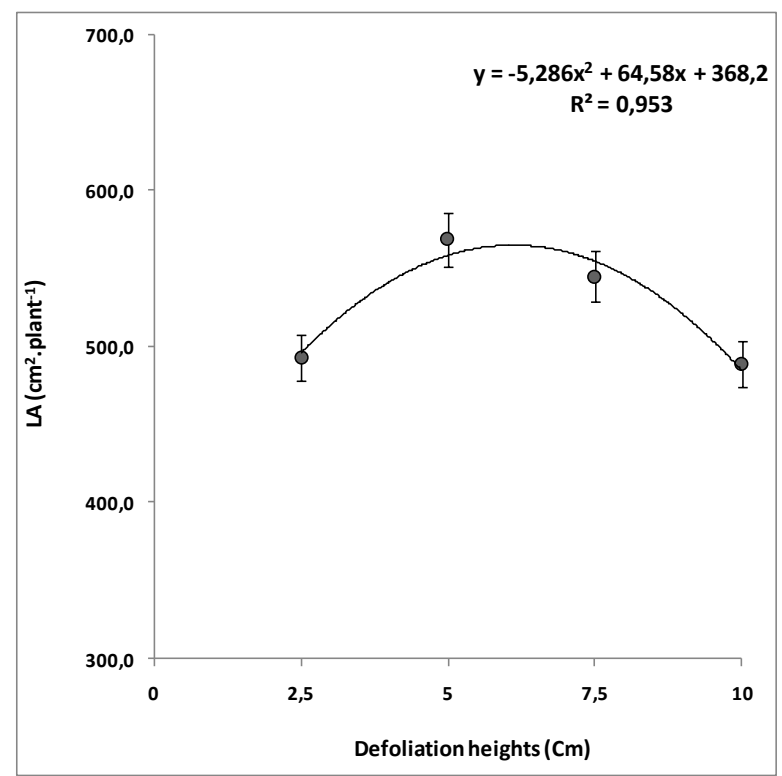

Figure 5. Leaf area (LA) of berseem Khadhraoui under different defoliation heights $(2.5-5-7.5$ and $10 \mathrm{~cm})$. Each point represents the mean of 4 individual values. Intervals of confidence were calculated at $\alpha=95 \%$.

\section{Specific leaf area $(S L A)$}

The Specific leaf area, expressed in $\mathrm{cm}^{2}$ per gram of dry matter of leaves is shown in figure 6 . The statistical analysis of the SLA shows a significant difference between the defoliation heights of 2.5 and $5 \mathrm{~cm}$, on one hand and those realized at 7.5 and $10 \mathrm{~cm}$, on the other hand. 


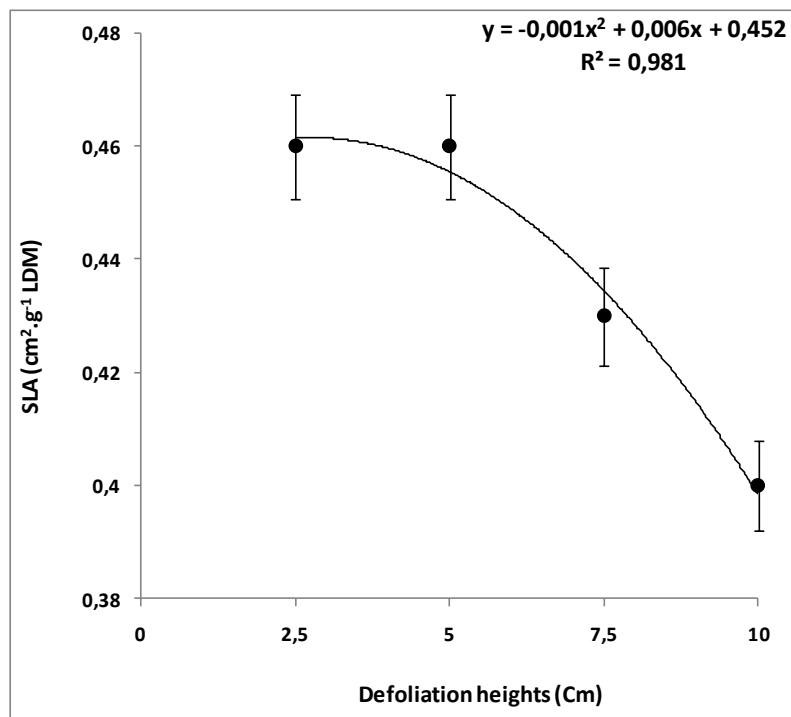

Figure 6. Specific Leaf area (SLA) of berseem Khadhraoui under different defoliation heights (2.5 - 5 - 7.5 and $10 \mathrm{~cm}$ ). Each point is the mean of 4 individual values. Intervals of confidence were calculated at $\alpha=95 \%$.

\section{Mineral contents in the organs of the berseem khadhraoui}

We studied the variation of the $\mathrm{K}^{+}, \mathrm{Ca}^{2+}$ and the inorganic phosphorus $(\mathrm{P})$ distributions in the biomass of roots, stems and leaves of the berseem Khadhraoui, harvested at different defoliation heights. The defoliation which constitutes in itself a mechanic stress, affects the balance of source-sink, as a result of a decrease in the photosynthesing leaves. The defoliation leads to a modification in the activity of the ionic demands in the regenerated vegetative organs. The balances in leaf and stem transports and the root accumulation of the major cations $\left(\mathrm{K}^{+}\right.$and $\left.\mathrm{Ca}^{2+}\right)$, under different defoliation heights were studied at the beginning, in the middle and at the end of the experiment, respectively after $47-105$ and 175 days of the levying.

\section{Potassium content}

Figure 7A represents the variation of potassium contents in roots, stems and leaves according to the defoliation heights $(2.5-5-7.5$ and $10 \mathrm{~cm})$. Results showed that the $\mathrm{K}^{+}$contents in the stems and leaves are significantly higher than those in the roots. For all organs (root, stem and leaf), $\mathrm{K}^{+}$contents decreased significantly with the increase of the defoliation heights. That is $\mathrm{K}^{+}$content under the defoliation height of $2.5 \mathrm{~cm}$ was significantly higher than that of the stubble bases of $10 \mathrm{~cm}$ height. We have also studied the variation of the $\mathrm{K}^{+}$content at three different dates (the beginning, the middle and the end of the experiment). Figure 7B showed that $\mathrm{K}^{+}$content decreased with the time. The decrease in $\mathrm{K}^{+}$content in shoots (leaves and stems) and roots dry matter was the resulted from the depletion of the soil culture from the defoliation to another by the mass of dry matter harvested. 


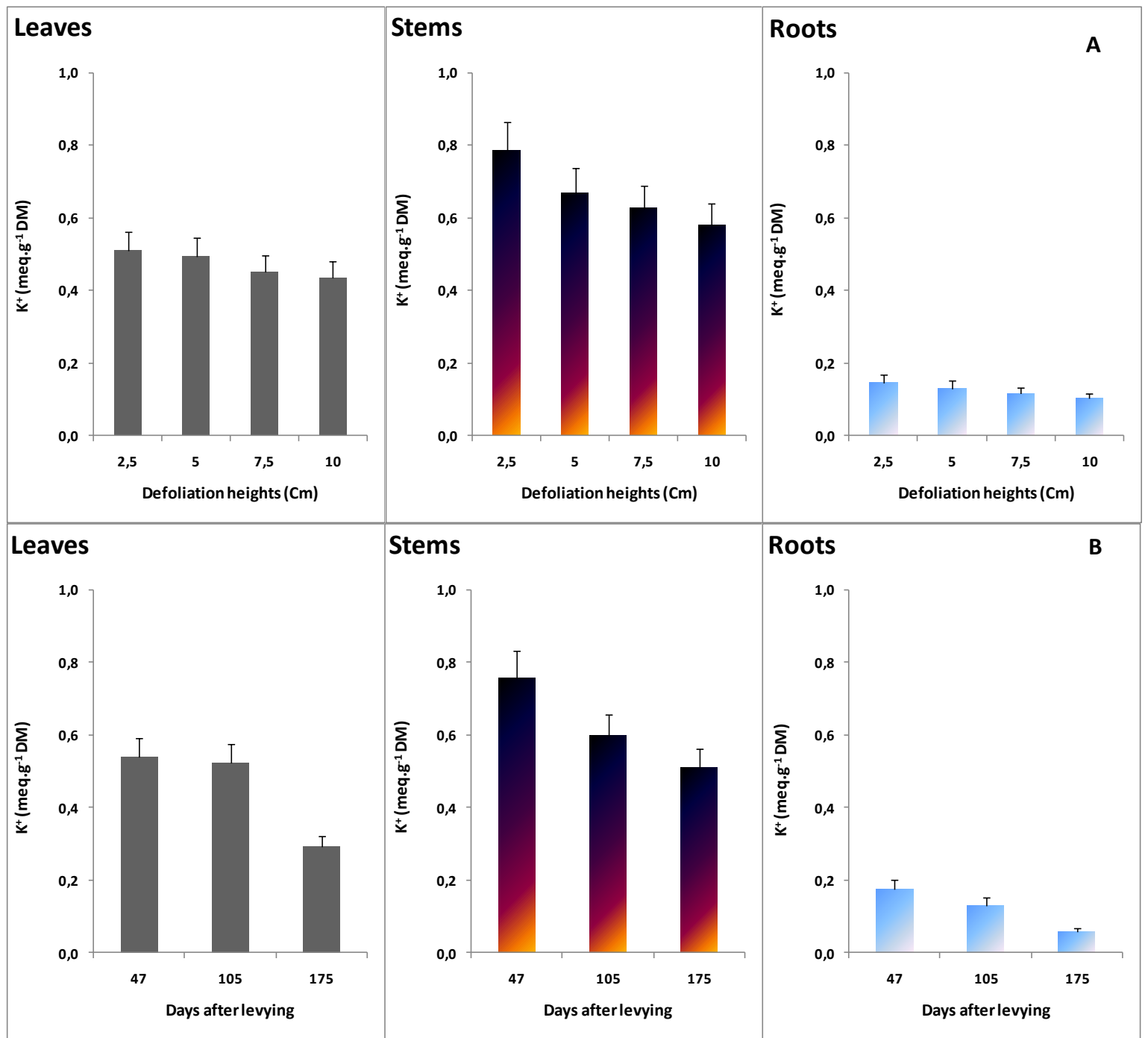

Figure 7. $\mathrm{K}^{+}$contents in leaves, stems and roots of berseem Khadhraoui under $(\underline{\mathbf{A}})$ different defoliation heights $(2.5-5-7.5$ and $10 \mathrm{~cm})$ and $(\underline{\mathbf{B}})(47-105$ and 175) days after levying. Each point represents the mean of 4 individual values. Intervals of confidence were calculated at $\alpha=95 \%$.

\section{Calcium content}

Figure $8 \mathrm{~A}$ represents the variation of calcium contents in roots, stems and leaves according to the defoliation heights (2.5 - $5-7.5$ and $10 \mathrm{~cm})$. Results showed no significant difference of calcium contents in the dry matter of roots, stems and leaves between the defoliation heights. This can be explained by the soil high content in soluble active chalk which did not affected the $\mathrm{Ca}^{2+}$ content in the different plant parts (table 1).

The variation in the calcium content according to the duration of the experiment (number of days after the levying, figure $8 \mathrm{~B}$ ) showed that only the $\mathrm{Ca}^{2+}$ contents in roots decreased significantly with time. 


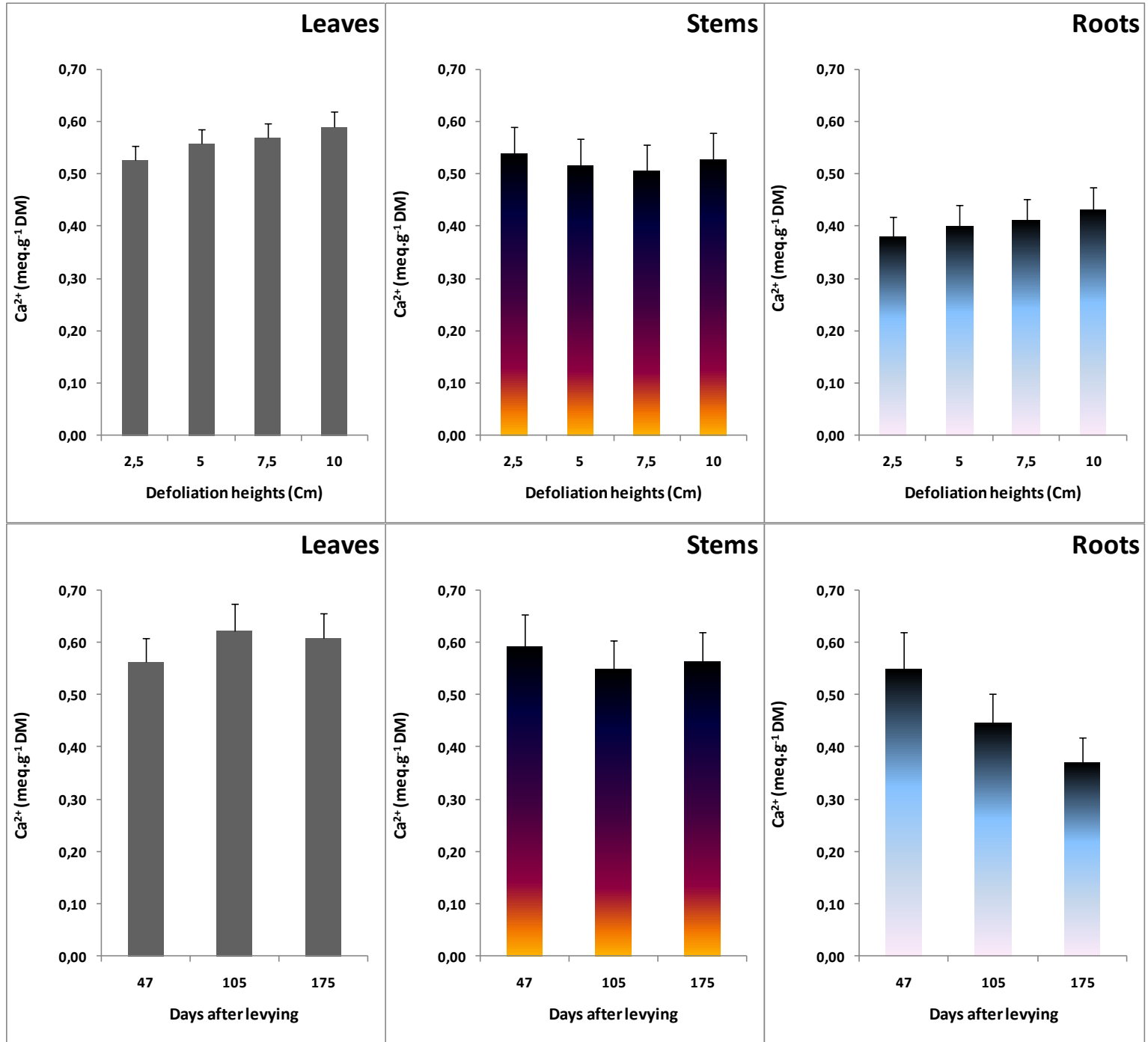

Figure 8. $\mathrm{Ca}^{2+}$ contents in leaves, stems and roots of berseem Khadhraoui under $(\underline{\mathbf{A}})$ different defoliation heights $(2.5-5-7.5$ and $10 \mathrm{~cm})$ and $(\underline{\mathbf{B}})(47-105$ and 175) days after levying. Each point is the mean of 4 individual values. Intervals of confidence were calculated at $\alpha=95 \%$.

\section{Phosphorus content}

The variation in phosphorus content in leaves, stems and roots according to the defoliation heights is given in figure 9A. We observe that leaves, and to a less degree stems have higher phosphorus content compared to roots. The $\mathrm{P}$ contents decreased significantly with the defoliation heights, due to the dilution by the growth.

Similarly, the phosphorus content in leaves, stems and roots decreases with the sampling duration (figure 9B). Indeed, we observed a significant decrease in phosphorus contents in the dry matter of the three organs, between the beginning, the middle and the end of the experiment. This is the result of the depletion of the culture medium in phosphorus which is indispensable to the growth and the development of the plants. 


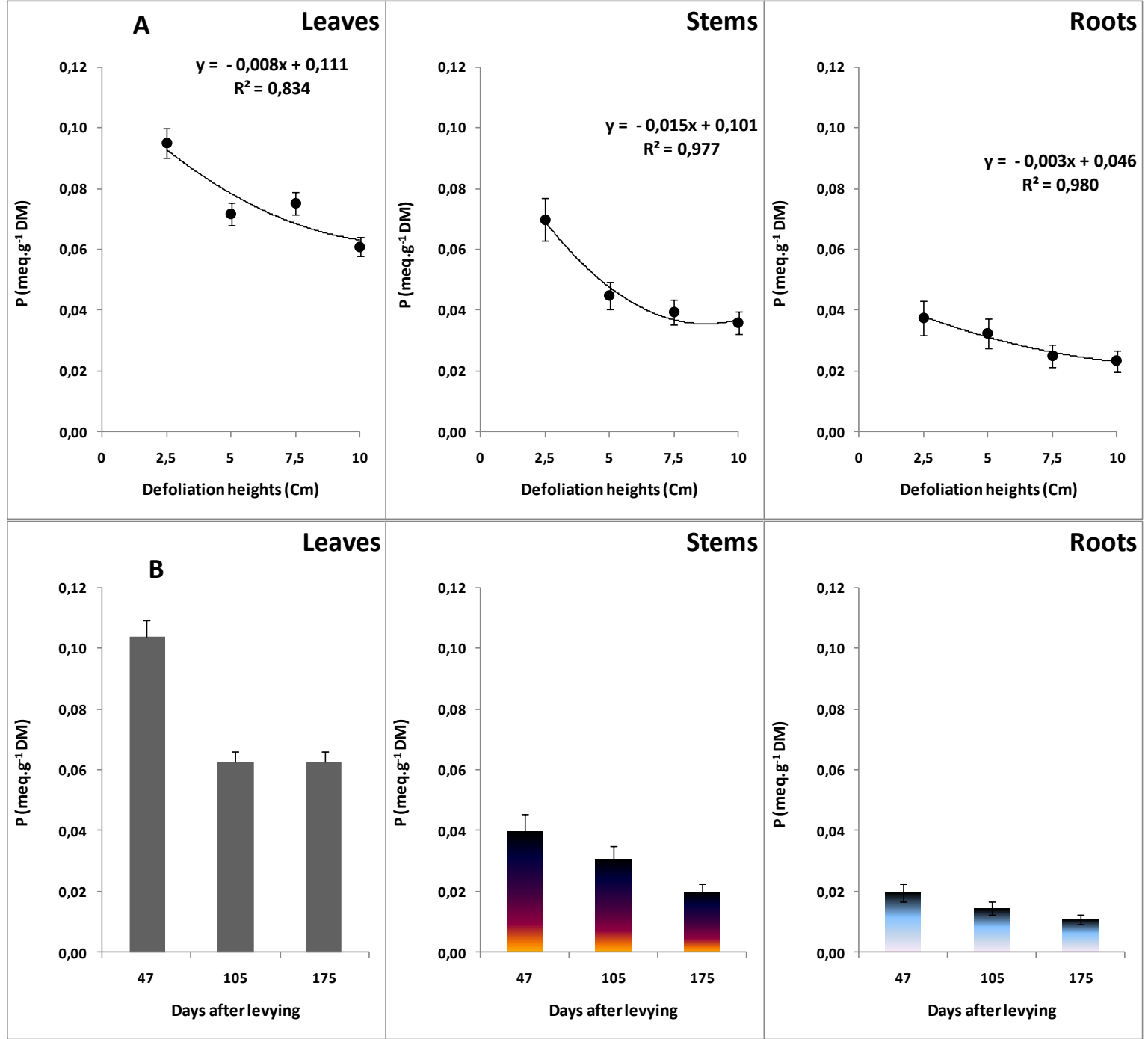

Figure 9. Phosphorus contents in leaves, stems and roots of berseem Khadhraoui under (ㅍ) different defoliation

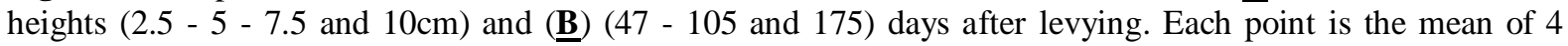
individual values. Intervals of confidence were calculated at $\alpha=95 \%$.

\section{Carbohydrate contents in berseem organs}

The reducing sugar contents in the three organs decreased significantly with the time. The decrease is very fast in roots, going from $56 \mathrm{mg} . \mathrm{g}^{-1} \mathrm{DM}$ after 47 days of the levying to $20 \mathrm{mg}^{-1} \mathrm{~g}^{-1} \mathrm{DM}$ after 175 days of the levying which a decline of $56 \%$, from the beginning of the experiment (fig. 10A).

As for soluble sugars, total sugars decreased according to the duration of the experiment in leaves, stems and roots of berseem Khadhraoui. The decrease of the total sugars in roots is very fast, going from $13.33 \mathrm{mg}$. $\mathrm{g}^{-1} \mathrm{DM}$ after 47 days of the levying to $5.83 \mathrm{mg}^{-\mathrm{g}^{-1}} \mathrm{DM}$ after 175 days of the levying, that is a decline of $64 \%$ (fig. $10 \mathrm{~B}$ ). 


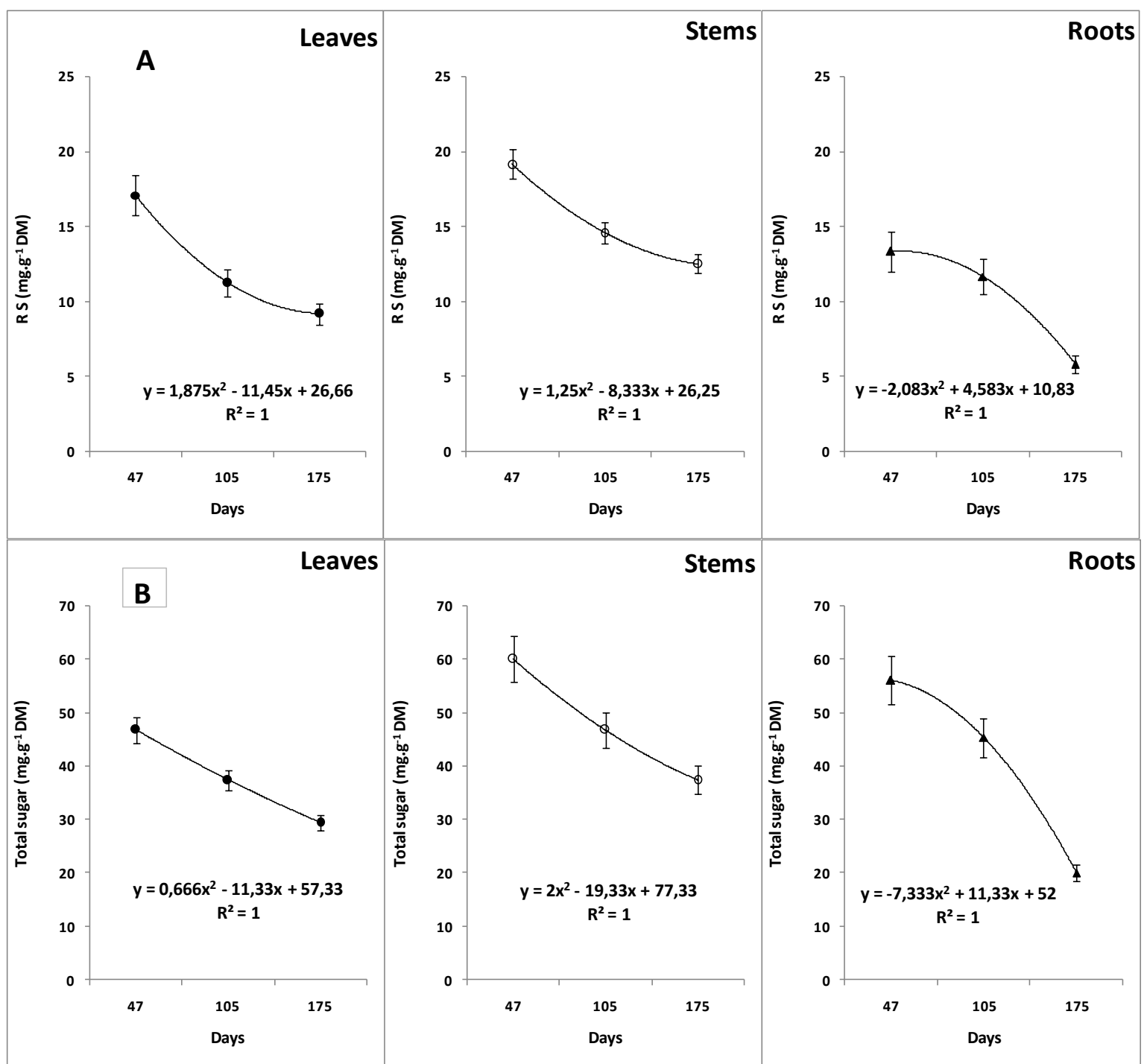

Figure 10. $(\underline{\mathbf{A}})$ Reducing sugar $(\mathrm{RS})$ and $(\underline{\mathbf{B}})$ total sugar contents in leaves, stems and roots of berseem Khadhraoui, at 47 - 105 and 175 days after levying. Each point is the mean of 4 individual values. Intervals of confidence were calculated at $\alpha=95 \%$.

\section{Discussion}

The objective of this work was to study the effect of the defoliation heights $(2.5-5-7.5$ and $10 \mathrm{~cm})$ on the growth, the mineral nutrition and the carbohydrate contents in the berseem Khadhraoui. The speed of the regrowth depends on the plant parts remaining below the the defoliation height level, which is depending on the quantity of green limbs left by the defoliation and on the quantity of soluble carbohydrates stored in roots at the defoliation time. Results showed that the cumulative dry material varies with the defoliation heights. So, in the sixth harvest, DM under the cutting height of $5 \mathrm{~cm}$ is significantly higher, than in the other treatments.

Our results confirm those found by Burns et al., (2002) on the tall fescue (Festuca arundinacea) and by Leconte (2002) with English rye-grass (Lolium perenne); where they found that the dry matter yield was significantly higher under the shortest defoliation height. This can be explained by the fact that grasses can emit new tillers which replace those harvested, while the morphology of the berseem and alfalfa regrowth is constituted at the same time by parts left after defoliation and by the neoformed stems from the crown (Dufour et al., 1989). However, our results do not agree with those reported by Brathen and Odasz-albrigtsen (2000) in Luzula arcuata, Hendrickson and Berdahl, (2002) in Thinopyrum intermedium and by Onyeonagu and Ugwuanyi (2012) in Panicum maximum.

The leaf area (LA) per plant showed a depressive effect of the extreme defoliations: shorter $(2.5 \mathrm{~cm})$ and higher $(10 \mathrm{~cm})$, while the cutting heights at 5 and $7.5 \mathrm{~cm}$ present a LA appreciably similar. Meuriot et al., (2004) reported that initial residual leaf area and initial $\mathrm{N}$ reserves influenced alfalfa regrowth and the residual leaf area had a greater effect on final forage production. Our results agree with those found by Giambalvo et al., (2011b) on berseem clover. 
The specific leaf area (SLA) decreased with the increase of the defoliation heights and a significant difference is clear between plants defoliated at 2.5 and $5 \mathrm{~cm}$, on one hand and those harvested at 7.5 and $10 \mathrm{~cm}$, on the other hand. Figure 11 illustrated the correlation between the specific leaf area and the cumulated DM production. The correlation showed a highly significant linear relationship between DM and SLA $\left(\mathrm{R}^{2}=0.836\right)$ which explains the improvement in the photosynthetic efficiency of the berseem clover Khadhraoui.

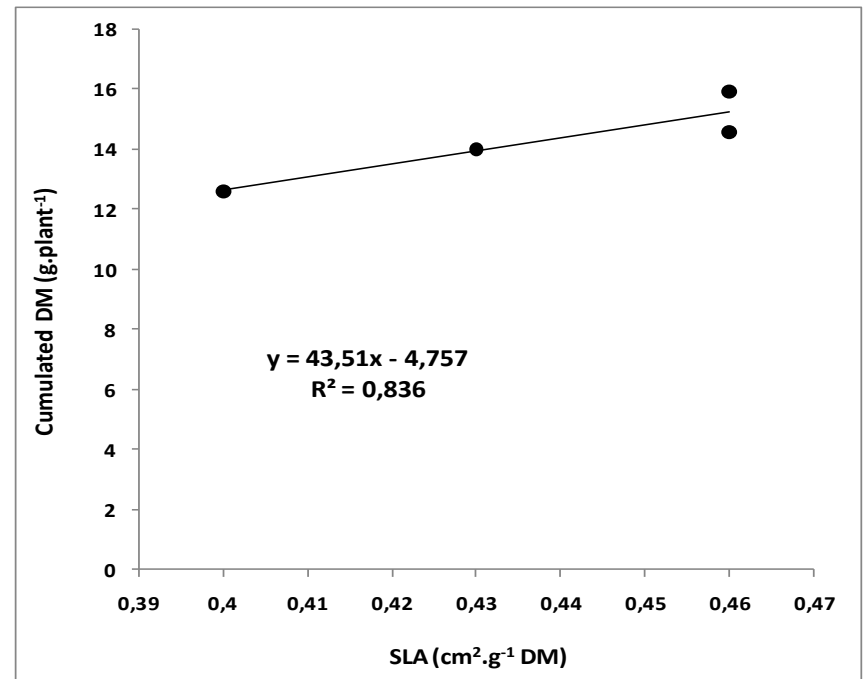

Figure 11. Correlation between cumulated dry matter and the SLA in the berseem Khadhraoui under different defoliation heights $(2.5-5-7.5$ and $10 \mathrm{~cm})$.

The distribution of the shoot dry matter between leaves and stems allows the appreciation of the fodder quality of the produced biomass. The defoliation heights of 2.5 and $5 \mathrm{~cm}$ have a fodder quality better than those of 7.5 and $10 \mathrm{~cm}$. Indeed, the short defoliations increase the formation of stems with many active leaves, while the highest defoliations stimulate the ramification of stems and activate the premature senescence of the old leaves left below the cutting level, resulting in an important mass of stems which depreciated fodder quality (photo 1).

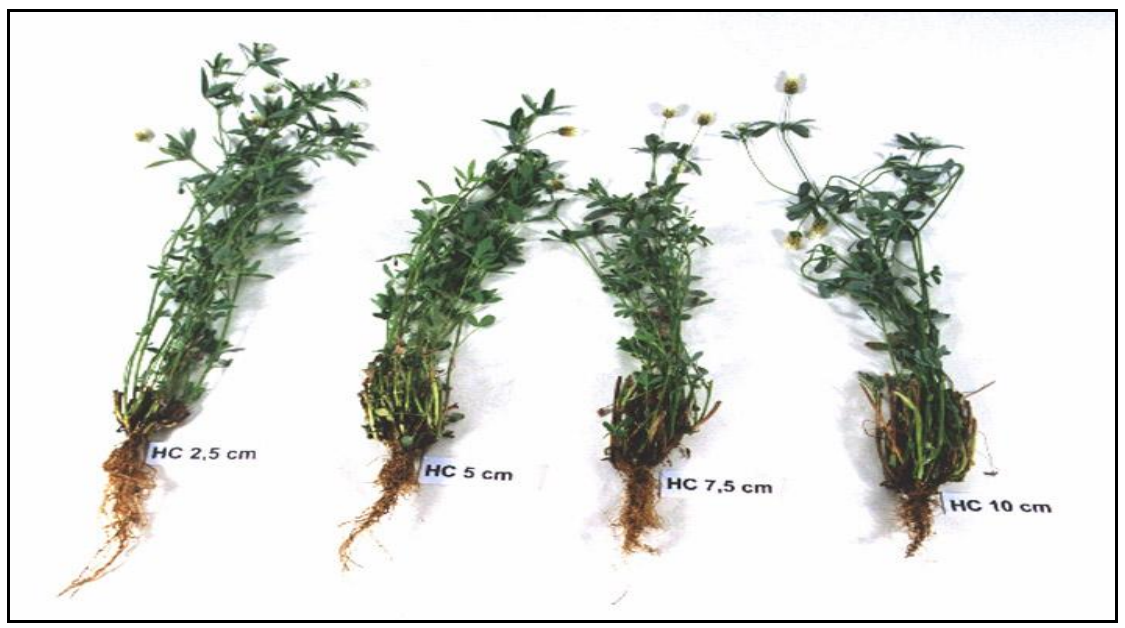

Photo 1. Effect of the cutting heights (HC) on the stubble bases of the berseem Khadhraoui

The distribution of photoassimilats between the shoots and roots (metabolites to be later reused in the regrowth) highlights the relation source/sink. Indeed, the shoots which contain leaves photosynthetically active produce photoassimilats or carbohydrates which a part migrate to the taproot and the crown to be stored and used later after defoliation to regenerate new leaves (Meuriot et al., 2004; Hopkins and Huner, 2008). In Lolium perenne and Calamagrostis epigejos, Louahlia et al., (1999), Gloser (2005); Kavanova' and Gloser, (2005) and Gloser et al., (2007) found that amino acids and soluble proteins from roots and stubble bases were the most important sources of storage compounds for regrowth of the shoot.

The $\mathrm{S} / \mathrm{R}$ ratio under the defoliation height of $5 \mathrm{~cm}$ was the lowest, compared to other treatments. This showed that the root DM increases under the defoliation height of $5 \mathrm{~cm}$ faster than that of the shoot DM, under the same treatment, which gives a shoot to root ratio significantly lower. Iannucci (2001) reported that just after cutting of two varieties of berseem, shoots are the main sinks, whereas roots and crowns represent the sources. 
The effect of the defoliation height on the mineral nutrition of the berseem Khadhraoui, exposed to the mechanical stress of defoliation was studied in three different dates (beginning $(47 \mathrm{~d})$, middle (105 d) and the end $(175 \mathrm{~d})$ of the experiment). In these conditions, the tolerance will depend largely, on the root system to supply plants with an adequate mineral nutrition indispensable for their growth and for their development after defoliation.

Potassium is a critical nutrient for the growth, development, and persistence. Although the $\mathrm{K}^{+}$content decreases according to the increase in the defoliation heights in the three organs of the berseem plants (fig. 7), the quantities of $\mathrm{K}^{+}$in shoots (stems and leaves), exported by the harvested biomass at the most extreme treatments $(2.5 \mathrm{~cm}=$ short cutting) and the highest $(10 \mathrm{~cm})$, increase linearly with the harvest date (fig. 12$)$. This uptake by the plants of berseem depletes the culture medium in $\mathrm{K}^{+}$, what is necessary to correct the soil deficiency in $\mathrm{K}^{+}$with a supply of potassium amendment. In a study on the effect of defoliation interval and height on the growth of Arachis pintoi, Sinclair et al., (2007) found that the level of $\mathrm{K}^{+}$in leaves decreased as the defoliation interval was extended and this effect was significant from 10 to 20 day intervals.

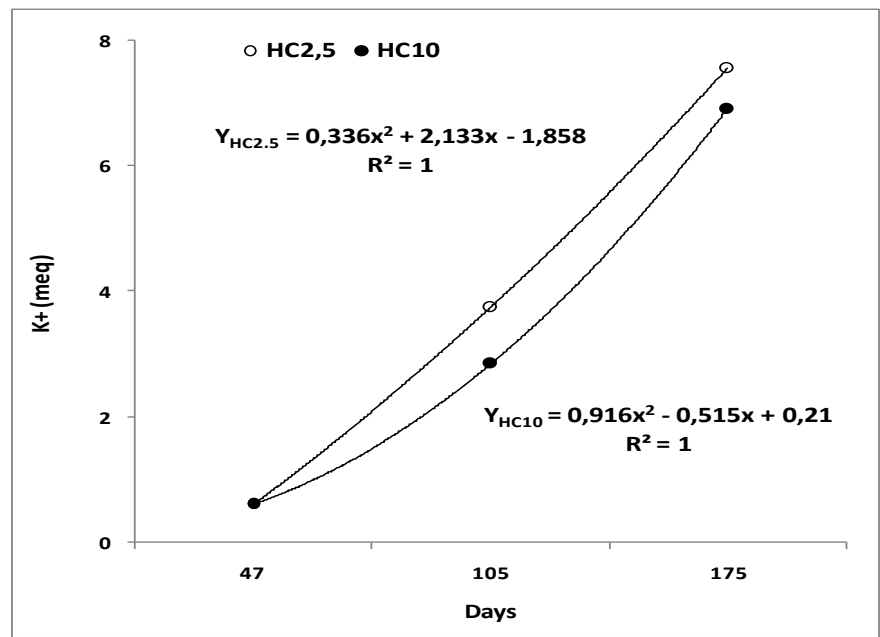

Figure 12. Quantity of potassium exported by berseem shoots under short $(2.5 \mathrm{~cm})$ and high $(10 \mathrm{~cm})$ defoliation at $47-105$ and 175 days after levying.

For calcium, results do not show any significant difference between the defoliation heights in stems and leaves (fig. 8). This is probably that the soil culture is very rich in active chalk (tab. 1). The phosphorus decreased significantly with the cutting heights and the time of the harvest (beginning, middle and the end of the experiment) in the three organs of the berseem Khadhraoui (fig. 9).

The study on the effect of defoliation heights on the growth and the productivity of biomass highlights the importance of the soluble sugar in the berseem Khadhraoui to regenerate shoots via the rémobilisation of the soluble carbohydrate reserves in crown and taproot. Indeed, the decrease of the soluble sugar contents in three organs of the berseem according to time shows a severe decline of such component in the root system. Teixeira et al., (2007) related the importance of the accumulation and depletion of $\mathrm{N}$ and $\mathrm{C}$ reserves in alfalfa crown and taproots in the shoot growth rate, mainly after defoliation and during early-spring regrowth.

\section{Acknowledgements}

This study was performed with the support of the Tunisia National Institute for Agricultural Research (INRAT) and the "Faculté des Sciences de Tunis".

\section{References}

[1]. Amiard V., Morvan-Bertrand A., Billard J-P., Huault C., Prud'homme M-P., 2003. Fate of fructose supplied to leaf sheaths after defoliation of Lolium perenne L.: assessment by ${ }^{13}$ C-fructose labeling. J. Exp. Bot., 54(385): 1231-1243.

[2]. Avice J.C., Louahlia S., Kim T.H., Jacquet A., Morvan-Bertrand A., Prudhomme M.P., Ourry A., Simon J.C., 2001. Influence des réserves azotées et carbonées sur la repousse des espèces prairiales. Fourrages, 165: 3-22.

[3]. Baatar B., 2008. Effects of cutting height and frequency on yield in a Mongolian rangeland, Land Restoration Training, 1-16.

[4]. Berg W.K., Cunningham S.M., Brouder S.M., Joern B.C., Johnson K.D., Volenec J.J., 2009. Influence of phosphorus and potassium on alfalfa yield, taproot $C$ and N pools, and transcript levels of key genes after defoliation. Crop Sci., 49(3): $974-982$.

[5]. Berthier A., Desclos M., Amiard V., Morvan-Bertrand A., Demmig-Adams B., Adams W.W., Turgeon R., Prud'homme M-P., Noiraud-Romy N., 2009. Activation of sucrose transport in defoliated Lolium perenne L.: An example of apoplastic phloem loading plasticity, Plant Cell Physiol. 50(7): 1329-1344.

[6]. Brathen K. A., Odasz-Albrigtsen A.M., 2000. Tolerance of the arctic graminoid Luzula arcuata ssp. Confusa to simulated grazing in two nitrogen environments. Can. J. Bot., 78: 1108-1113. 
[7]. Burns J.C., Chamblee D.S., Giesbrecht F.G., 2002. Defoliation intensity effects on season-long dry matter distribution and nutritive value of tall fescue. Crop Sci.. 42: 1274-1284.

[8]. Chen J-S., Tang F-L., Zhu R-F., Gao C., Di G-L., Zhang Y-X., 2012. Effects of cutting frequency on alfalfa yield and yield components in Songnen Plain, Northeast China. Afri. J. of Biotech., 11(21): 4782-4790.

[9]. Da Silveira M.C.T., Nascimento Júnior D., Da Cunha B.A.L., Difante G.S., Pena K.S., Da Silva S.C., Sbrissia A.F., 2010. Effect of cutting interval and cutting height on morphogenesis and forage accumulation of guinea grass (Panicum maximum). Tropical Grasslands, 44: 103-108.

[10]. De Santis G., Iannucci A., Dantone D., Chiaravalle E., 2004. Changes during growth in the nutritive value of components of berseem clover (Trifolium alexandrinum L.) under different cutting treatments in a Mediterranean region. Grass and Forage Sci., 59(4): 378388 .

[11]. Dhont C., Castonguay Y., Nadeau P., Langer G., Drapeau R., Laberge S., Avice J-C., Chalifour F-P., 2006. Nitrogen reserves, spring regrowth and winter survival of field-grown Alfalfa (Medicago sativa ) defoliated in the autumn. Annals of Botany, 97: 109-120.

[12]. Dufour L, Faucher M et Lemaire G (1989). Etudes des transferts d'assimilats entre les tiges de luzerne (Medicago sativa L.) par l'utilisation $\mathrm{du}^{14} \mathrm{CO}_{2}$. Agronomie. 9: 377-382.

[13]. El-Morsy M.H.M., 2009. Influence of cutting height and plant spacing on Sesbania (Sesbania aegyptiaca [Poir]) productivity under hyper-arid conditions in El-kharga Oasis, El-Wadi El-Gaded, Egypt. Inter. J. Plant Prod., 3(2): 1735-8043.

[14]. Garcia M.G., Busso C.A., Polci P., Garcia-Girou N. L., Echenique V., 2002. Water relations and leaf growth rate of three Agropyron genotypes under water stress. Biocell, 26: 309-317.

[15]. Garnier E., Laurent G., Bellmann A., Debain S., Berthelier P., Ducout B., Roumet C., Navas M.-L., 2001. Consistency of species ranking based on functional leaf traits. New Phytologist, 152: 69-83.

[16]. Giambalvo D., Ruisi P., Di Miceli G., Frenda A.S., Amato G., 2011a. Forage production, $\mathrm{N}$ uptake, $\mathrm{N}_{2}$ fixation, and N recovery of berseem clover grown in pure stand and in mixture with annual ryegrass under different managements. Plant Soil, 342(1): 379-391.

[17]. Giambalvo D., Amato G., Stringi L., 2011b. Effects of stubble height and cutting frequency on regrowth of berseem clover in a Mediterranean semiarid environment, Crop Sci., 51(4): 1808-1814.

[18]. Gloser V., 2005. The consequences of lower nitrogen availability in autumn for internal nitrogen reserves and spring growth of Calamagrostis epigejos. Plant Ecology, 179:119-126.

[19]. Gloser V., Košvancová M., Gloser J., 2007. Regrowth dynamics of Calamagrostis epigejos after defoliation as affected by nitrogen availability, Biologia Plantarum 51(3): 501-506.

[20]. Gordon A.J., Kessler W., Minchin F.R., 1999. Defoliation induced stress in nodules of white clover. J. Exp. Bot., 41: 1245-1253.

[21]. Goulas E., Le Dily F., Simon J-C., Ourry A., 2002. Morphological pattern of development affects the contribution of nitrogen reserves to regrowth of defoliated white clover (Trifolium repens L.). J. Exp. Botany, 53(376): 1941-1948.

[22]. Hendrickson J.R., Berdahl J.D., 2002. Intermediate wheatgrass and Russian wild rye responses to defoliation and moisture. J. Range Manage., 55: 99-103.

[23]. Hopkins W.G., Huner N.P.A., 2008. Introduction to Plant Physiology, Fourth Edition, Wiley Publisher House, 503pp.

[24]. Iannucci A., 2001. Effects of harvest management on growth dynamics, forage and seed yield in berseem clover. Eur. J. Agro., 14: 303-314.

[25]. Iannucci A., Martiniello P., 2000. Berseem growth response to different cutting regimes. In Sulas L. (ed.). Legumes for Mediterranean forage crops, pastures and alternative uses. CIHEAM-IAMZ, 287-291.

[26]. Johansson G., 1993. Carbon distribution in grass (Festuca pratensis L.) during regrowth after cutting-utilization of stored and newly assimilated carbon. Plant and Soil, 151: 11-20.

[27]. Kavanova M., Gloser V., 2005. The use of internal nitrogen stores in the rhizomatous grass Calamagrostis epigejos during regrowth after defoliation, Annals of Botany, 95: 457-463,

[28]. Leach G.J., 1968. The regrowth of Lucerne plant after cutting: The effects of cutting at different stage of maturity and at different intensities. Aust. J. Agric. Res., 19: 517-530.

[29]. Leconte D., 2002. Importance du rythme et de la hauteur de défoliation du ray-grass anglais sur la composition morphologique des repousses. Fourrages, 169: 47-63.

[30]. Lee J.M., Sathish P., Donaghy D. J., Roche J.R., 2010. Plants modify biological processes to ensure survival following carbon depletion: a Lolium perenne model. Plos One, 5(8): 1-10.

[31]. Lemaire G., Genier G., Lila M., 1994. Growth dynamics and digestibility for two genotypes of Lucerne having different morphology. In management and breeding of perennial Lucerne for diversified purpose. Eucarpia-Reur, FAO, 36: 75-77.

[32]. Lestienne F., Thornton B., Gastal F., 2006. Impact of defoliation intensity and frequency on N uptake and mobilization in Lolium perenne. J. of Exper. Botany, 57(4): 997-1006.

[33]. Louahlia S., Macduff J.H., Ourry A., Humphreys M., Boucaud J., 1999. Nitrogen reserve status affects the dynamics of nitrogen remobilization mineral nitrogen uptake during recovery of contrasting cultivars of Lolium perenne from defoliation. New Phytol., 142: $451-462$.

[34]. Meuriot F., Avice J.-C., Simon J.-C., Laine P., Decau M.-L., Ourry A., 2004. Influence of initial organic N reserves and residual leaf area on growth, $\mathrm{N}$ uptake, $\mathrm{N}$ partitioning and $\mathrm{N}$ storage in alfalfa (Medicago sativa) during post-cutting regrowth. Annals of Botany, 94: $311-321$.

[35]. Mezni M. et Sifi B., 1995. Réponses des Medicago annuels à l'inoculation dans le semi-aride Tunisien. In Drevon J.J. (éd.). "Facteurs limitant la fixation symbiotique de l'azote dans le bassin méditerranéen". Les colloques 77: 291-297.

[36]. Mezni M., Bizid E., Kalboussi R., 2000. Recherche d'associations fourragères adaptées en Tunisie. Cas de l'association bersim-raygrass d'Italie en zone irrigable. Fourrages, 161: 61-68.

[37]. Morvan-Bertrand A., Boucaud J., Prud'Homme M-P., 1999. Influence of initial levels of carbohydrates, fructans, nitrogen and soluble proteins on regrowth of lolium perenne L. Cv. Bravo following defoliation. J. Exp. Bot., 50: 1817-1826.

[38]. Onyeonagu C. C., Ugwuanyi B. N., 2012. Influence of cutting height and nitrogen fertilization on plant height and tiller production of guinea grass (Panicum maximum Jacq) pasture. Afr. J. Agric. Res., 7(48): 6401-6407.

[39]. Peyraud J.L., Le Gall A., Lüscher A., 2009. Potential food production from forage legume-based-systems in Europe: an overview. Irish J. Agric. and Food Res., 48: 115-135.

[40]. Schnyder H., De visser R., 1999. Fluxes of reserve drived and currently assimilated carbon and nitrogen in perennial ryegrass recovering from defoliation. The regrowing tiller and its component functionally distinct zones. Plant Physiol., 119: 1423-1435.

[41]. Simon J.C., Jacquet A., Decau M.L., Goulas E., Le Dily F., 2004. Influence of cutting frequency on the morphology and the C and N reserve status of two cultivars of white clover (Trifolium repens L.). Europ. J. Agronomy, 20: 341-350.

[42]. Sinclair K., Lowe K.F., Pembleton K.G., 2007. Effect of defoliation interval and height on the growth and quality of Arachis pintoi cv. Amarillo. Tropical Grasslands, 41: 260-268. 
[43]. Teixeira E.I., Moot D.J., Mickelbart M.V., 2007. Seasonal patterns of root C and N reserves of Lucerne crops (Medicago sativa L.) grown in a temperate climate were affected by defoliation regime. Eur. J. Agronomy, 26: 10-20.

[44]. Tessem Z. K., Mihret J., Solomon M., 2010. Effect of defoliation frequency and cutting height on growth, dry-matter yield and nutritive value of Napier grass (Pennisetum purpureum (L.) Schumach). Grass and Forage Sci., 65: 421-430.

[45]. Undersander D. J., Pinkerton B. W., 1989. Utilization of alfalfa, Forages, 15: 1-3.

[46]. Vinther F. P., 2006. Effects of cutting frequency on plant production, $\mathrm{N}$-uptake and $\mathrm{N}_{2}$ fixation in above- and below-ground plant biomass of perennial ryegrass--white clover swards. Grass and Forage Sci., 61: 154-163.

[47]. Wijitphan S., Lorwilai P., Arkaseang C., 2009. Effect of cutting heights on productivity and quality of king napier grass (Pennisetum purpureum cv. King Grass) under irrigation. Pakistan J. of Nutrition, 8(8): 1244-1250. 